\title{
Pengaruh Model Pembelajaran Creative Problem Solving dalam Pembelajaran Jarak Jauh terhadap Kemampuan Pemecahan Masalah Matematis Siswa SMP Negeri 3 Jakarta
}

\author{
Naila Nur Fadhila ${ }^{1, \text { a) }}$, Lukman El Hakim², Vera Maya Santi ${ }^{3}$ \\ ${ }^{123}$ Universitas Negeri Jakarta, Rawamangun, Jakarta Timur \\ Email penulis: a) nailanurfadhila_1301617027@mhs.unj.ac.id
}

\begin{abstract}
The purpose of this study was to examine the effect of the Creative Problem-Solving learning model in distance learning on the mathematical problem-solving abilities of SMP Negeri 3 Jakarta students. This study uses a quasi-experimental method with a posttest-only control group design. The sampling technique was two-stage random sampling using cluster random sampling and simple random sampling. The instrument used is a mathematical problem-solving ability test on comparative material in the form of 4 description questions that have been tested for validity and reliability. Based on the results of data analysis using the t-test, it is found that $t_{\text {count }}$ is 3.765 and $t_{\text {table }}$ is 1.665 , so reject $\mathrm{H} 0$ with a significance level of $=0.05$ with a Cohen's effect size value of 0.858 which is collected in the large category with a percentage of $79 \%$. Thus, it can be explained that there is a significant effect of the Creative Problem-Solving learning model on students' mathematical problem-solving abilities in PJJ at SMP Negeri 3 Jakarta on comparative material.
\end{abstract}

Keywords: Creative Problem-Solving Learning Model, Distance Learning, Mathematical Problem-Solving Ability.

\begin{abstract}
Abstrak
Tujuan dari penelitian ini adalah untuk menguji pengaruh model pembelajaran Creative Problem Solving dalam pembelajaran jarak jauh terhadap kemampuan pemecahan masalah matematis siswa SMP Negeri 3 Jakarta. Penelitian ini mempergunakan metode quasi-experiment dengan posttest-only control group design. Teknik pengambilan sampel dengan two stage random sampling menggunakan cluster random sampling dan simple random sampling. Instrumen yang dipergunakan ialah tes kemampuan pemecahan masalah matematis pada materi perbandingan berupa 4 soal uraian yang telah diuji validitas dan reliabilitasnya. Berdasar pada hasil analisis data mempergunakan uji-t didapatkan $t_{\text {hitung }}$ sebesar 3,765 dan $t_{\text {tabel }}$ sebesar 1,665 sehingga tolak $\mathrm{H}_{0}$ dengan taraf signifikansi $\alpha=0,05$ dengan nilai Cohen's effect size senilai 0,858 yang terhimpun pada kategori besar dengan persentase 79\%. Dengan demikian, dapat dipaparkan bahwa terdapat pengaruh signifikan dari model pembelajaran Creative Problem Solving terhadap kemampuan pemecahan masalah matematis siswa dalam PJJ di SMP Negeri 3 Jakarta pada materi perbandingan.
\end{abstract}

Kata kunci: Model Pembelajaran Creative Problem Solving, Pembelajaran Jarak Jauh, Kemampuan Pemecahan Masalah Matematis.

Copyright (c) 2020 Fadhila, Hakim, Santi

$\square$ Corresponding author:

Email Address: nailanurfadhila_1301617027@mhs.unj.ac.id

Received 3 Februari 2020, Accepted 10 Februari 2020, Published 20 Februari 2020

https://doi.org/10.21009/jrpmj.v2i1.12123

\section{PENDAHULUAN}

Pendidikan adalah aspek penting yang dibutuhkan dalam kehidupan manusia. Melalui pendidikan, manusia memiliki aspek-aspek yang dapat menunjang kehidupannya menjadi lebih terarah serta dapat menghargai kebudayaan dan norma-norma bangsa. Dalam mengikuti perkembangan zaman, peningkatan kualitas pendidikan sangat dibutuhkan dalam kehidupan manusia di berbagai bidang 
(Hasiani, 2019). Dengan memperoleh pendidikan, manusia mampu membuat potensi yang terdapat dalam dirinya makin berkembang.

Dalam proses pendidikan, banyak pelajaran yang mempunyai peranan penting, salah satunya adalah matematika. Matematika dipelajari semenjak taraf SD hingga SMA, bahkan hingga di taraf perguruan tinggi pun matematika masih tetap dipelajari. Selain itu, matematika juga lebih banyak dipelajari di sekolah, hal tersebut dapat diamati dari jam mata pelajaran matematika yang memiliki alokasi waktu lebih banyak dibanding mata pelajaran lainnnya. Ujian untuk masuk ke jenjang lebih tinggi juga menggunakan mata pelajaran matematika sebagai pelajaran yang diujikan. Hal tersebut mengindikasikan bahwa matematika memiliki peran yang penting dalam dunia pendidikan.

Dalam pembelajaran matematika, siswa akan berhadapan dengan berbagai macam permasalahan. Masalah yang diberikan akan memicu siswa untuk berpikir (Prasetiyo dkk., 2015). Untuk mengerti sebuah materi, memahami saja tidak cukup, siswa dituntut untuk dapat menguasai kemampuan guna memecahkan permasalahan. Pemecahan masalah adalah dasar dalam pembelajaran matematika, jika siswa mengalami kesulitan guna memecahkan permasalahan, maka siswa pun akan mengalami kesulitan guna mengerjakan soal matematika. Kemampuan guna memecahkan permasalahan matematika merupakan kemampuan siswa guna menyelesaikan permasalahan berupa soal yang tidak rutin yang tidak mampu diselesaikan secara langsung, namun membutuhkan konsep lain dan langkahlangkah untuk menyelesaikannya (Muslim, 2017).

Ada empat tahap yang dikemukakan Polya dalam pemecahan soal pemecahan permasalahan, yaitu pemahaman permasalahan, perencanaan pemecahan, pemecahan permasalahan sesuai dengan rencana yang dibuat, dan pemeriksaan kembali seluruh langkah yang telah dilaksanakan (Polya, 1957). Menurut Pehkonen, terdapat empat alasan penting pemberian pemecahan permasalahan, yaitu: (1) mampu membuat keterampilan kognitif makin berkembang, (2) mampu membuat kreativitas makin meningkat, (3) merupakan bagian dari proses implementasi matematika, (4) mampu menjadi motivasi bagi siswa supaya mempelajari matematika (dalam Setiawan \& Harta, 2014). Pada penelitian ini, indikator kemampuan pemecahan masalah matematis siswa yang hendak dipergunakan adalah indikator yang diutarakan oleh Lestari \& Yudhanegara (2015) yaitu sebagai berikut: (1) Mengidentifikasikan berbagai unsur yang diidentifikasi, unsur yang ditanyakan, serta banyaknya unsur yang dibutuhkan, (2) Melakukan perumusan permasalahan matematika ataupun penyusunan model matematika, (3) Mengimplementasikan strategi guna memecahkan berbagai permasalahan, (4) Menginterpretasikan solusi dari permasalahan melalui penggunaan matematika secara bermakna.

Fakta di lapangan memperlihatkan bahwa kemampuan siswa guna memecahkan permasalahan matematika masih relatif rendah. Hal itu bisa diamati melalui hasil Programme for International Student Assessment (PISA) 2018 yang dilaksanakan oleh OECD dengan rerata 374 di tahun 2018 dan 386 di tahun 2015. Terdapat penurunan skor PISA dari tahun 2015 ke 2018 (OECD, 2019). Didukung dengan hasil survei 4 tahunan TIMSS yang didiskusikan oleh IEA (The International Association for the Evaluation of Educational Achievement), nilai rata-rata pada TIMSS 2011 siswa Indonesia capaian 
rata-ratanya hanya 386, yang artinya nilai tersebut berada di tingkat yang rendah. Rata-rata ini mengalami penurunan dari hasil sebelumnya yaitu pada TIMSS 2007 yang memperoleh skor 397 (Rosnawati, 2013).

Begitu pula dengan temuan pengamatan yang dilaksanakan di SMP Negeri 3 Jakarta. Berlandaskan wawancara dengan guru matematika, didapatkan temuan bahwa kurang baiknya kemampuan pemecahan masalah yang dimiliki siswa karena saat diberikan beberapa soal yang tak rutin oleh guru yang membutuhkan pemecahan masalah, mereka masih kesulitan dalam menggunakan prinsip dan aturan yang benar, serta menghubungkan informasi menjadi kesatuan yang utuh, sehingga siswa tidak mampu guna memecahkan soal tersebut dengan tepat. Persentase soal UN yang mengukur kemampuan pemecahan masalah matematis siswa sebesar $25 \%$ dan 32,5\%, sedangkan rata-rata nilai UN tahun ajaran 2017/2018 dan 2018/2019 yang didapat melalui Puspendik hanya sebesar 60,54 dan 62,79. Hal tersebut membuktikan bahwa kemampuan pemecahan masalah matematis siswa masih rendah.

Guna menyikapi berbagai permasalahan yang telah disampaikan, perlu diterapkan aktivitas pembelajaran yang bermakna untuk siswa. Hal tersebut selaras dengan penelitian yang diselenggarakan oleh Farnika yang mengemukakan bahwa guna membuat kemampuan pemecahan masalah yang makin meningkat, maka guru harus memberikan ruang gerak pada siswa guna mampu menyatakan berbagai gagasan dan ide yang dimilikinya. (Farnika dkk., 2015). Pernyataan tersebut menunjukkan bahwa diperlukannya aktivitas pembelajaran yang menunjang siswa supaya lebih aktif sehingga pembelajaran berfokus pada siswa (student centered). Namun terdapat keterbatasan dalam dunia pendidikan pada masa covid-19. Covid-19 merupakan peyakit baru yang sebelumnya tak pernah ditelaah manusia. Covid-19 memiliki gejala dan tanda umum pada manusia yang terinfeksi seperti gangguan pernapasan, batuk, demam, dan sesak napas dengan masa inkubasi paling lama yaitu 14 hari. Oleh karena itu, WHO menetapkan pada tanggal 30 Januari 2020 sebagai keadaan darurat terkait kesehatan masyarakat yang mengubah dunia (Dewi, 2020). Salah satu imbas dari covid-19 adalah berlakunya pembelajaran jarak jauh.

Pembelajaran jarak jauh ialah kegiatan belajar mengajar yang berlangsung ketika siswa dan guru secara fisik dan secara bersamaan tidak berada di tempat yang sama (Setiawan, 2020). Berlandaskan wawancara dengan guru matematika di SMP Negeri 3 Jakarta didapatkan hasil bila pembelajaran jarak jauh yang telah diselenggarakan selama ini hanya sebatas pemberian materi pembelajaran, penugasan, dan tanya jawaab. Hal ini mengakibatkan adanya keterbatasan siswa dalam menuangkan gagasan-gagasannya dan mengeksplor materi pembelajaran sehingga menghambat kemampuan pemecahan masalah matematika.

Berlandaskan keadaan yang terjadi, maka guru sangat perlu menentukan pembelajaran yang bisa memantik siswa lebih aktif dalam berpikir, menjalin komunikasi guna mengumpulkan data, serta mencari pemecahan guna permasalahan yang ditemukan sehingga mampu membuat kemampuan pemecahan masalah makin meningkat meskipun pembelajaran yang dilaksanakan adalah pembelajaran 
jarak jauh. Adapun model yang berkaitan dengan pemecahan masalah ialah model pembelajaran Creative Problem Solving.

Creative Problem Solving merupakan tipe pembelajaran di mana yang menjadi pusat dalam pengajarannya ialah kemampuan dan keterampilan terkait pemecahan masalah. Dari permasalahanpermasalahan yang disajiikan oleh guru, siswa akan dilatih agar lebih aktif ketika melaksanakan diskusi, berpikir kritis, aktif, serta menjalin kerja sama supaya solusi atas permasalahan tersebut dapat ditemukan melalui penggunaan urutan langkah yang telah ditetapkan. Langkah-langkah tersebut, yaitu: mengklarifikasi permasalahan, pengumpulan data, mengidentifikasi seluruh solusi yang tersedia dan memungkinkan guna dilaksanakan serta implementasi (Herlawan \& Hadija, 2017). Beberapa keunggulan yang dimiliki oleh model pembelajaran Creative Problem Solving, di antaranya ialah: 1) Membiasakan peserta didik guna membuat suatu model dalam sebuah penemuan, 2) Mampu realistis dalam menghadapi masalah yang akan dipecahkan, 3) Berpikir dan bertindak kreatif, 4) Memahami dan melaksanakan analisis, 5) Menginterpretasikan dan mengevaluasi solusi dalam pengamatan, 6) Mengembangkan kemampuan siswa guna memecahkan permasalahan dengan tepat (Shoimin, 2014). Penelitian terdahulu yang relevan dengan penelitian ini disajikan singkat dalam uraian berikut.

1. Maharani (2020) dalam penelitiannya yang berjudul "Pengaruh Model Creative Problem Solving (CPS) dalam Pembelajaran Jarak Jauh terhadap Kemampuan Berpikir Kritis Matematis Siswa di SMAN 14 Bekasi". Berlandaskan hasil analisis melalui uji-t, thitung yang didapat adalah 5,385 dan ttabel yang didapat adalah 1,66. Hal itu mengakibatkan $\mathrm{H} 0$ ditolak dan dapat ditarik simpulan bahwa model Creative Problem Solving dalam pembelajaran jarak jauh memberi pengaruh pada kemampuan berpikir kritis matematis.

2. Evendi (2019) dalam penelitiannya yang berjudul "Pengaruh Model Pembelajaran CPS Terhadap Pemecahan Masalah dan Kecemasan Matematis Ditinjau dari KAM" menyimpulkan berlandaskan hasil analisis ditemukan bahwa kemampuan pemecahan masalah dari siswa yang diajar melalui model Creative Problem Solving mendapat hasil yang lebih baik dibanding siswa yang dididik melalui pembelajaran konvensional.

3. Sutiawan (2017) dalam penelitian yang dilakukannya dengan judul "Penggunaan Pembelajaran Creative Problem Solving (CPS) dalam Upaya Meningkatkan Kemampuan Pemecahan Masalah Matematis dan Self Efficacy Siswa SMP" menyimpulkan berdasarkan data penelitian dan analisis data bahwa kemampuan pemecahan masalah matematis siswa yang mengaktualisasikan pembelajaran dengan model Creative Problem Solving mendapat hasil yang lebih baik dibanding siswa yang mengaktualisasikan pembelajaran kovensional.

\section{METODE}

Metode yang digunakan dalam penelitian ini adalah metode eksperimen semu dengan desain penelitian Posttest-Only Control Group Desain. Populasi terjangkau pada penelitian ini adalah siswa 
kelas VII SMP Negeri 3 Jakarta tahun ajaran 2020/2021. Teknik pengambilan sampel menggunakan Two Stage Sampling, yaitu Cluster Random Sampling dan Simple Random Sampling. Tahap pertama Cluster Random Sampling, terpilih kelas VII yang dijadikan sebagai populasi terjangkau. Tahap kedua adalah Simple Random Sampling, yaitu pengambilan 2 dari 4 kelas yang telah lolos uji prasyarat analisis data sebelum perlakuan. Satu kelas sebagai kelas eksperimen dengan 40 siswa VII E) yang belajar menggunakan model pembelajaran Creative Problem Solving dalam pembelajaran jarak jauh dan satu kelas sebagai kelas kontrol dengan 37 siswa (VII D) yang belajar menggunakan model pembelajaran konvensional dalam pembelajaran jarak jauh.

Data yang diambil untuk penelitian ini adalah hasil Penilaian Akhir Semester (PAS) kelas VII semester ganjil tahun ajaran 2020/2021 dan hasil post test dengan jumlah siswa kelas eksperimen 40 siswa dan jumlah siswa kelas kontrol 37 siswa. Hasil PAS digunakan untuk uji prasyarat analisis data sebelum perlakuan untuk menentukan kelas eksperimen dan kelas kontrol. Adapan hasil post test digunakan untuk uji prasyarat analisis data setelah perlakuan, uji analisis data dan uji besar pengaruh. Teknik pengumpulan data dilakukan dengan memberikan post test kemampuan pemecahan masalah matematis kepada siswa kelas eksperimen dan kelas kontrol pada bahasan perbandingan. Instrument post test di validasi oleh dua validator ahli dari dosen pendidikan matematika universitas negeri jakarta dan satu guru matematika di SMP Negeri 3 Jakarta. Berikut contoh soal yang digunakan dalam penelitian:

Tabel 1. Soal Instrumen Tes Kemampuan Pemeahan Masalah Matematis

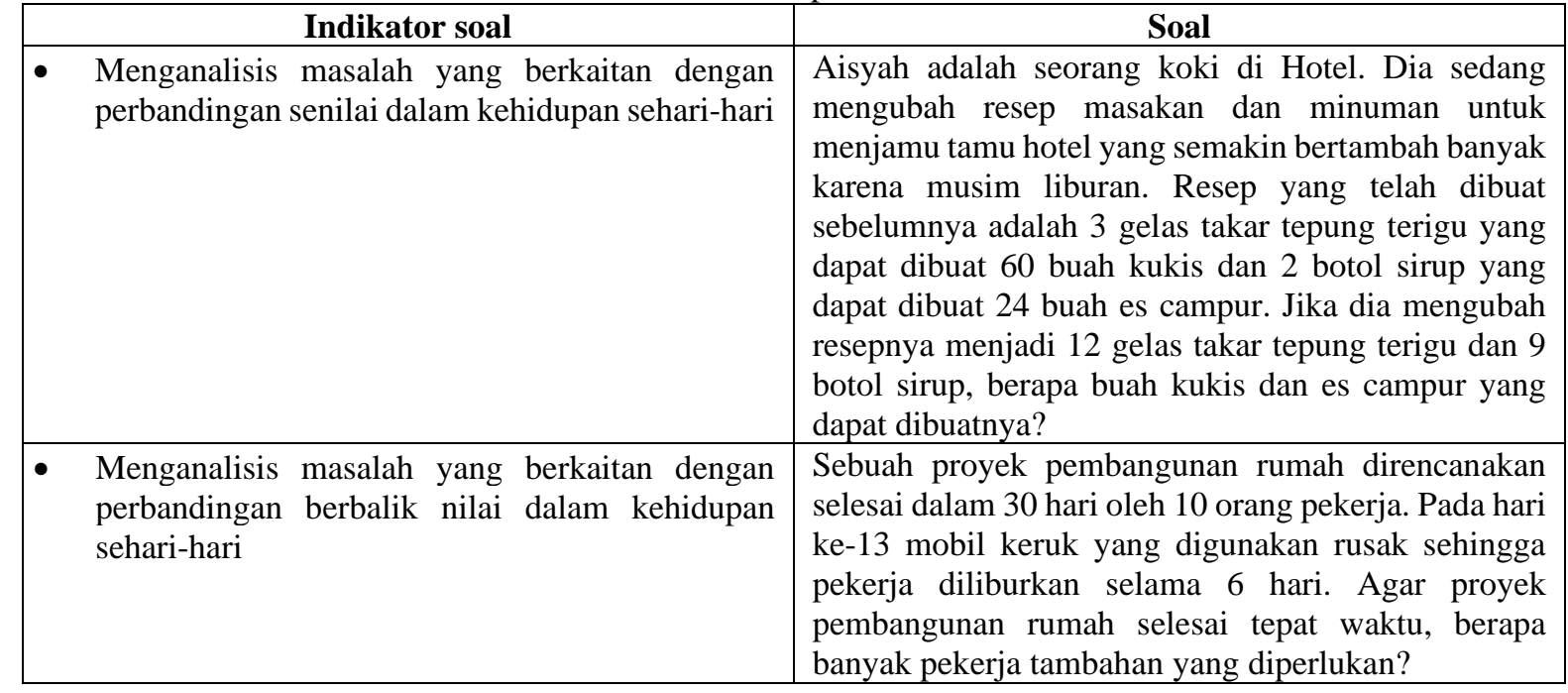

Hasil uji validitas instrumen tes dapat dilihat pada Tabel 2 berikut:

TABEL 2. Hasil Uji Validitas Instrumen Tes

\begin{tabular}{|c|c|c|c|}
\hline No Soal & Koefisien Validitas & Keterangan & Kriteria \\
\hline 1 & 0,714 & Valid & Tinggi \\
\hline 2 & 0,690 & Valid & Tinggi \\
\hline 3 & 0,746 & Valid & Tinggi \\
\hline
\end{tabular}




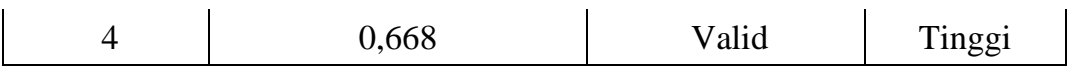

Berdasarkan Tabel 2, diperoleh semua butir soal berkisar pada rentang 0 sampai 1, maka dapat dikatakan semua butir soal instrumen penelitian bernilai valid. Koefisien butir soal nomor 1 senilai 0,714 yang dikategorikan tinggi, koefisien butir soal nomor 2 senilai 0,690 yang dikategorikan tinggi, koefisien butir soal nomor 3 sebesar 0,746 yang dikategorikan tinggi, dan koefisien butir soal nomor 4 sebesar 0,668 dikategorikan tinggi.

\section{HASIL DAN PEMBAHASAN}

Uji Prasyarat Analisis Data Sebelum Perlakuan

Hasil uji normalitas sebelum perlakuan disajikan dalam Tabel 3.

Tabel 3. Hasil Uji Normalitas Sebelum Perlakuan
\begin{tabular}{|c|c|c|c|c|c|}
\hline Kelas & $\mathbf{n}$ & $\boldsymbol{L}_{\text {hitung }}$ & $\boldsymbol{L}_{\text {tabel }}$ & Keterangan & Kesimpulan \\
\hline VII C & 40 & 0,129 & 0,140 & $L_{\text {hitung }}<L_{\text {tabel }}$ & Terima $H_{0}$ \\
\hline VII D & 37 & 0,099 & 0,146 & $L_{\text {hitung }}<L_{\text {tabel }}$ & Terima $H_{0}$ \\
\hline VII E & 40 & 0,136 & 0,140 & $L_{\text {hitung }}<L_{\text {tabel }}$ & Terima $H_{0}$ \\
\hline VII F & 40 & 0,103 & 0,140 & $L_{\text {hitung }}<L_{\text {tabel }}$ & Terima $H_{0}$ \\
\hline
\end{tabular}

Berdasarkan Tabel 3, diketahui bahwa seluruh kelas yang diuji memiliki nilai $L o<$ Ltabel, artinya keputusan terima $H_{0}$. Hal ini memberikan kesimpulan bahwa keempat kelas yaitu VII C, VII D, VII E, serta VII F bersumber dari populasi yang terdistribusi secara normal dan bertingkat signifikansi $5 \%$. Hasil uji homogenitas sebelum perlakuan disajikan dalam Tabel 4.

Tabel 4. Hasil Uji Homogenitas Sebelum Perlakuan

\begin{tabular}{|c|c|c|}
\hline $\boldsymbol{X}^{\mathbf{2}}{ }_{\text {hitung }}$ & $\boldsymbol{X}^{\mathbf{2}}{ }_{\text {tabel }}$ & Interpretasi \\
\hline 5,423 & 0,220 dan 7,815 & Homogen \\
\hline
\end{tabular}

Berdasarkan tabel 4, dapat diketahui bahwa $\chi_{\left(\frac{\alpha}{2}, d k\right)}^{2}<\chi_{\text {hitung }}^{2}<\chi_{\left(1-\frac{\alpha}{2}, d k\right)}^{2}=0,220<5,423<7,815$ maka $H_{0}$ diterima, sehingga dapat ditarik simpulan bahwa distribusi keempat kelas pada kelas VII C, VII D, VII E, serta VII F memiliki varian yang relatif homogen atau tidak berbeda secara signifikan dengan taraf nyata $5 \%$.

Hasil uji kesamaan rata-rata disajikan dalam Tabel 5.

Tabel 5. Hasil Uji Kesamaan Rata-rata

\begin{tabular}{|c|c|c|c|c|c|}
\hline $\begin{array}{c}\text { Sumber } \\
\text { Variansi }\end{array}$ & Dk & JK & KT & $\boldsymbol{F}_{\text {hitung }}$ & \multirow{2}{*}{$\boldsymbol{F}_{\text {tabel }}$} \\
\cline { 1 - 5 } Total & 156 & 66500,828 & & 2,540 & $\begin{array}{c}0,072 \\
\text { dan }\end{array}$ \\
\cline { 1 - 5 } Antar & 3 & 3155,310 & 1051,77 & & \multirow{2}{*}{}
\end{tabular}




\begin{tabular}{|l|l|l|l|l|l|} 
Dalam & 153 & 63345,518 & 414,023 & 3,203 \\
\hline
\end{tabular}

Berdasarkan tabel 5 yang disajikan, dapat ditarik simpulan bahwasanya $F_{\text {hitung }}=2,540$, $F_{\left(1-\frac{\alpha}{2}, d k_{A}, d k_{D}\right)}=0,072$, dan $F_{\left(\frac{\alpha}{2}, d k_{A}, d k_{D}\right)}=3,203$. Hasil perhitungan tersebut menunjukkan bahwa $F_{\left(1-\frac{\alpha}{2}, d k_{A}, d k_{D}\right)}<F_{\text {hitung }}<F_{\left(\frac{\alpha}{2}, d k_{A}, d k_{D}\right)}$ sehingga dapat ditarik simpulan bahwa $H_{0}$ diterima. Maka dari itu, distribusi keempat kelas pada kelas VII C, kelas VII D, kelas VII E, serta kelas VII F nilai rataratanya tidak berbeda secara signifikan dengan taraf nyata $5 \%$.

\section{Uji Prasyarat Analisis Data Setelah Perlakuan}

Hasil uji normalitas setelah perlakuan disajikan dalam Tabel 6.

TABEL 6. Hasil Uji Normalitas Setelah Perlakuan

\begin{tabular}{|c|c|c|c|c|c|}
\hline Kelas & $\mathbf{N}$ & $\boldsymbol{L}_{\text {hitung }}$ & $\boldsymbol{L}_{\text {tabel }}$ & Keterangan & Kesimpulan \\
\hline $\begin{array}{c}\text { Eksperimen } \\
\text { (VII E) }\end{array}$ & 40 & 0,111 & 0,140 & $L_{\text {hitung }}<L_{\text {tabel }}$ & Terima $H_{0}$ \\
\hline $\begin{array}{c}\text { Kontrol (VII } \\
\text { D) }\end{array}$ & 37 & 0,112 & 0,146 & $L_{\text {hitung }}<L_{\text {tabel }}$ & Terima $H_{0}$ \\
\hline
\end{tabular}

Berdasarkan tabel 6, didapatkan bahwa $L_{\text {hitung }}$ kelas eksperimen dan kelas kontrol lebih kecil dari $L_{\text {tabel }}$, maka terima $H_{0}$. Berdasar pada hasil tersebut, dapat ditarik simpulan bahwasanya data setelah diberikan perlakuan dari kelas eksperimen dan kelas kontrol diambil dari populasi yang teralokasi secara normal dan bertaraf nyata $5 \%$.

Hasil uji homogenitas setelah perlakuan disajikan dalam Tabel 7.

Tabel 7. Hasil Uji Homogenitas Setelah Perlakuan

\begin{tabular}{|c|c|c|c|c|}
\hline $\boldsymbol{F}_{\text {hitung }}$ & $\boldsymbol{F}_{\left(\mathbf{1}-\frac{\mathbf{1}}{2} \boldsymbol{\alpha}\right)\left(\boldsymbol{n}_{\mathbf{1}} \mathbf{- 1}, \boldsymbol{n}_{\mathbf{2}}-\mathbf{1}\right)}$ & $\boldsymbol{F}_{\left(\frac{\mathbf{1}}{2} \boldsymbol{\alpha}\right)\left(\boldsymbol{n}_{\mathbf{1}}-\mathbf{1}, \boldsymbol{n}_{\mathbf{2}}-\mathbf{1}\right)}$ & Keterangan & Kesimpulan \\
\hline & & & $F_{\left(1-\frac{1}{2} \alpha\right)\left(n_{1}-1, n_{2}-1\right)}$ & \\
1,243 & 0,520 & 1,908 & $\begin{array}{l}<F_{\text {hitung }} \\
<F_{\left(\frac{1}{2} \alpha\right)\left(n_{1}-1, n_{2}-1\right)}\end{array}$ & Terima $H_{0}$ \\
& & & \\
\hline
\end{tabular}

Berdasarkan tabel 7 di atas didapatkan bahwa $F_{\text {hitung }}=1,243$ sedangkan $F_{\left(1-\frac{1}{2} \alpha\right)\left(n_{1}-1, n_{2}-1\right)}=0,520$ dan $F_{\left(\frac{1}{2} \alpha\right)\left(n_{1}-1, n_{2}-1\right)}=1,908$, maka terima $H_{0}$. Maka dari itu, dapat ditarik simpulan bahwa data setelah perlakuan dari kelas eksperimen dan kelas kontrol bervarian relatif homogen ataupun tidak berbeda secara signifikan dengan taraf nyata $5 \%$.

\section{Uji Analisis Data}


Hasil uji kesamaan rata-rata disajikan dalam Tabel 8.

Tabel 8. Hasil Uji-t Dua Sampel Independen

\begin{tabular}{|c|c|c|c|}
\hline $\boldsymbol{t}_{\text {hitung }}$ & $\boldsymbol{t}_{\text {tabel }}$ & Keterangan & Keputusan \\
\hline 3,765 & 1,665 & $t_{\text {hitung }}>t_{\text {tabel }}$ & Tolak $H_{0}$ \\
\hline
\end{tabular}

Berdasarkan tabel 8, dapat diamati bahwa nilai $t_{\text {hitung }}$ yaitu 3,765 lebih besar daripada nilai $t_{\text {tabel }}=$ $t_{(1-\alpha)\left(n_{1}+n_{2}-2\right)}=t_{(0,95)(75)}=1,665$, maka tolak $H_{0}$. Jadi, hal tersebut mengimplikasikan bahwa kemampuan pemecahan masalah siswa yang diajar melalui Creative Problem Solving pada kelas eksperimen bernilai rata-rata lebih tinggi dibandingkan rata-rata dari kemampuan pemecahan masalah matematis siswa kelas kontrol yang diajar melalui pembelajaran konvensional dalam PJJ dengan taraf nyata $5 \%$.

Uji Besar Pengaruh

Hasil uji besar pengaruh disajikan dalam Tabel 9.

Tabel 9. Hasil Uji Cohen's

\begin{tabular}{|c|c|c|}
\hline Cohen's effect size & Persentase & Kategori \\
\hline 0,858 & $79 \%$ & Besar \\
\hline
\end{tabular}

Berdasarkan tabel 9 di atas, nilai Cohen's effect size adalah sebesar 0,858 sehingga termasuk dalam kategori besar dengan persentase 79\%. Maka dari itu, dapat ditarik simpulan bahwa pembelajaran model Creative Problem Solving dalam PJJ berpengaruh besar terhadap kemampuan pemecahan masalah matematis siswa SMP Negeri 3 Jakarta yaitu sebesar $79 \%$.

\section{PEMBAHASAN}

Hasil tes kemampuan pemecahan masalah matematis menunjukkan bahwa siswa kelas eksperimen bernilai rata-rata 71,146, sementara hasil tes kemampuan pemecahan masalah matematis siswa kelas kontrol nilai rata-ratanya adalah 56,475 pada materi perbandingan.. Kelas eksperimen belajar dengan model Creative Problem Solving dalam pembelajaran jarak jauh, sedangkan kelas kontrol belajar dengan model pembelajaran konvensional dalam pembelajaran jarak jauh.

Perbedaan hasil yang didapat dari kedua model pembelajaran terjadi dikarenakan terdapatnya beberapa perbedaan perlakuan selama aktivitas pembelajaran, ialah:

1. Tahap pembelajaran

Pembelajaran dengan tipe Creative Problem Solving dilakukan mulai dari pembuka, inti pembelajaran dan penutup. Pembukaan pembelajaran dilakukan melalui Whatsapp Group, kemudian guru membentuk siswa menjadi beberapa kelompok untuk mengerjakan LKPD. Selanjutnya guru memberikan link Google Meet untuk menyampaikan tujuan dan materi pelajaran. Setelah itu, guru meminta siswa guna membahas LKPD di grup kecil yang telah dibuat oleh guru. Pada tahap pertama, 
yakni tahap klarifikasi masalah, siswa secara berkelompok diberikan permasalahan dalam bentuk LKPD untuk kemudian dirumuskan oleh siswa.

Tahap berikutnya adalah pengungkapan pendapat. Pada tahapan ini, siswa diberikan kebebasan guna mengutarakan pendapat terkait strategi-strategi dalam menyelesaikan masalah. Siswa diarahkan oleh guru untuk melakukan diskusi melalui Whatsapp Group dan semua anggota kelompok bebas mengutarakan pendapat terkait beraneka ragam strategi guna menyelesaikan masalah. Jika tidak ada yang mengungkapkan pendapatnya, maka guru memberi rangsangan pada siswa berupa beraneka ragam pertanyaan yang berkorelasi dengan materi yang tengah dibahas pada pertemuan terkait.

Tahap yang ketiga yaitu evaluasi dan pemilihan ide. Semua kelompok diminta untuk menyelesaikan masalah dengan cara mendiskusikan pendapat-pendapatnya. Siswa meninjau kembali pendapatnya melalui pemberian penjelasan dari tiap pendapat yang telah diutarakan. Selanjutnya pendapat-pendapat tersebut ditinjau oleh siswa dan setiap pendapat yang diungkapkan diberikan penjelasan. Kemudian, siswa memilih alternatif yang dinilai paling baik guna dibuat menjadi solusi.

Tahap yang terakhir adalah implementasi. Siswa memilih strategi mana yang berkemungkinan untuk diimplementasikan guna menyelesaikan permasalahan, lalu siswa mengimplementasikannya hingga mendapat pemecahan guna permasalahan tersebut. Selanjutnya, guru meminta tiap kelompok guna mengumpulkan jawaban LKPD pada Google Classroom. Setelah semua kelompok sudah mengumpulkan jawabannya, guru meminta perwakilan dua kelompok guna menjelaskan dan mengevaluasi jawaban dari permasalahan yang telah disajikan melalui Whatsapp Group yang berisi semua siswa. Guru mempersilahkan siswa guna mengajukan pertanyaan mengenai masalah yang diberikan. Setelah itu, guru dan siswa berbarengan mengambil simpulan terkait materi yang dibahas pada pertemuan tersebut. Dalam setiap kegiatan belajar mengajar dengan model Creative Problem Solving, siswa sangat berperan aktif karena pembelajaran berfokus pada siswa. Guru mempunyai peranan menjadi fasilitator serta pembimbing siswa sampai menemukan pemecahan masalah yang diharapkan.

Hal yang berbeda diimplementasikan pada kelas kontrol. Dalam penelitian ini, kelas kontrol mendapat pembelajaran berupa model konvensional. Pada penelitian ini, pembelajaran konvensional ialah kegiatan belajar mengajar yang kerap diselenggarakan oleh guru dan siswa. Pembukaan pembelajaran ini melalui penggunaan Whatsapp Group. Selanjutnya, guru memberikan link Google Meet guna menyampaikan materi pelajaran. Setelah itu, guru meminta siswa guna mengerjakan LKPD secara sendiri-sendiri, jika siswa ada yang kesulitan dalam mengerjakan LKPD, guru meminta siswa untuk bertanya, namun pada kenyataannya siswa masih kurang aktif untuk bertanya dalam pembelajaran.

Pada pembelajaran konvensional ini terlihat bahwa kurang mendapat respon baik dari siswa dan siswa cenderung hanya mengikuti apa yang diberikan oleh guru saja. Kemudian, guru menyimpulkan terkait materi yang dipelajari dan menutup pembelajaran. Pembelajaran ini terlihat bahwa peran guru lebih dominan dari awal sampai akhir. Pada kelas eksperimen yang 
mengaktualisasikan pembelajaran melalui pengimplemetasian Creative Problem Solving, guru memiliki peran sebagai fasilitator, guru hanya memandu jalannya pembelajaran dan mengevaluasi materi yang dipelajari. Hal tersebut membuat siswa aktif selama pembelajaran yaitu dengan berdiskusi dengan teman serta berdiskusi dengan guru jika masih ada yang kurang jelas. Guru juga menilai dan memastikan bahwa siswa dapat mengeksplor kemampuan pemecahan masalah matematisnya melalui LKPD yang diberikan. Dalam mengerjakan LKPD, siswa diberikan kebebasan untuk mengembangkan pengetahuannya terhadap masalah yang ada pada LKPD.

Adapun peran guru pada model pembelajaran konvensional adalah sebagai penyaji materi, siswa cenderung kurang aktif dan guru memegang peran besar dari awal sampai dengan pembelajaran berakhir sehingga kegiatan belajar mengajar hanya berlangsung satu arah. Akibat dari kebiasaan ini, siswa menjadi kurang mampu untuk mengeksplor kemampuannya dan tidak terbiasa menemukan secara mandiri keterkaitan antara satu materi dengan materi lainnya. Akhirnya, siswa kurang mampu mengoptimalkan kemampuan pemecahan masalah matematis. Dengan begitu, kemampuan pemecahan masalah matematis siswa yang dididik melalui model Creative Problem Solving lebih tinggi dibanding siswa yang dididik melalui pembelajaran konvensional. Oleh karena itu, bisa ditarik simpulan bahwa model Creative Problem Solving memberi pengaruh yang signifikan pada kemampuan pemecahan masalah matematis siswa dalam PJJ kelas VII SMP N 3 Jakarta pada pokok bahasan perbandingan.

\section{KESIMPULAN}

Berdasarkan rumusan masalah, hasil analisis data, dan pembahasan yang telah diuraikan pada bab sebelumnya, didapat nilai $t_{\text {hitung }}=3,765$ dan $t_{\text {tabel }}=1,665$. Hal ini menunjukkan bahwa rata-rata kemampuan pemecahan masalah matematis siswa SMP Negeri 3 Jakarta yang belajar menggunakan model Creative Problem Solving lebih tinggi daripada rata-rata kemampuan pemecahan masalah matematis siswa yang belajar dengan menggunakan model pembelajaran konvensional dalam pembelajaran jarak jauh pada pokok bahasan Perbandingan. Selain itu, dapat disimpulkan bahwa model Creative Problem Solving dalam pembelajaran jarak jauh memiliki pengaruh signifikan sebesar 79\% terhadap kemampuan komunikasi matematis siswa SMP Negeri 3 Jakarta.

Beberapa hal yang direkomendasikan untuk peneliti selanjutnya adalah melakukan perluasan terhadap penelitian ini. Seperti melakukan di sekolah yang jangkauannya lebih luas, melakukan penelitian pada materi yang berbeda, memperpanjang masa pembelajaran, serta melakukan perbaikanperbaikan teknis berdasarkan penelitian yang sudah dilakukan.

\section{DAFTAR PUSTAKA}

Dewi, W. A. F. (2020). Dampak COVID-19 terhadap Implementasi Pembelajaran Daring di Sekolah Dasar. Edukatif: Jurnal Ilmu Pendidikan, 2(1), 55-61. https://doi.org/10.31004/edukatif.v2i1.89

Evendi, H. (2019). Pengaruh Model Pembelajaran Cps Terhadap Pemecahan Masalah Dan Kecemasan Matematis Ditinjau Dari Kam. Prosiding Seminar Nasional \& Call For Papers, 218-224. 
Farnika, N., Ikhsan, M., \& Sofyan, H. (2015). Peningkatan Kemampuan Pemahaman dan Pemecahan Masalah Matematis Siswa Sekolah Menengah Atas dengan Model Pembelajaran Kooperatif Tipe Team Assisted Individualization. Jurnal Elemen, 1(2), 144. https://doi.org/10.29408/jel.v 1i2.146

Hasiani, O. V. (2019). Pengaruh Model Pembelajaran REACT Berbantuan Lembar Kegiatan Siswa (LKS) Terstruktur Terhadap Kemampuan Berpikir Kritis Matematis Siswa di SMP Negeri 6 Jakarta. Tesis Universitas Negeri Jakarta.

Herlawan, \& Hadija. (2017). Peningkatan Kemampuan Pemecahan Masalah Matematis Siswa Kelas VII Melalui Penerapan Model Pembelajaran Creative Problem Solving (CPS) Berbasis Kontekstual. EDU-MAT: Jurnal Pendidikan Matematika, 3(1), 166-175.

Lestari, K. E., \& Yudhanegara, M. R. (2015). Penelitian Pendidikan Matematika. Refika Aditama.

Maharani, N., Murdiyanto, T., \& Hadiyan, A. (2020). Pengaruh Model Pembelajaran Creative Problem Solving (CPS) dalam Pembelajaran Jarak Jauh (PJJ) terhadap Kemampuan Berpikir Kritis Matematis Siswa. Jurnal Riset Pendidikan Matematika Jakarta, 3(1), 48-57.

Muslim, S. R. (2017). Pengaruh Penggunaan Model Project Basedl Learning Terhadap Kemampuan Pemecahan Masalah Matematis Peserta Didik. Supremum Journal of Mathematics Education, $1(2), 88-95$.

OECD. (2019). Programme for International Student Assesment.

Polya, G. (1957). How to Solve It. Princeton University Press.

Prasetiyo, L. F., Rahayu, W., \& Indiyah, F. H. (2015). Perbedaan Kemampuan Pemecahan Masalah Matematis Siswa yang Diajar Menggunakan Model Pembelajaran Problem Based Learning dan Model Pembelajaran Ekspositori Berbantuan Software Geogebra di SMA Perguruan Rakyat 3 Jakarta. Tesis Universitas Negeri Jakarta.

Rosnawati, R. (2013). Kemampuan Penalaran Matematis Siswa SMP Indonesia pada TIMSS 2011. Prosiding Seminar Nasional Penelitian, Pendidikan Dan Penerapan MIPA, 1-6. http://staffnew.uny.ac.id/upload/132001808/penelitian/Makalah+Semnas+2013+an+R+Rosnawa ti+FMIPA+UNY.pdf

Setiawan, A. R. (2020). Lembar Kegiatan Literasi Saintifik untuk Pembelajaran Jarak Jauh Topik Penyakit Coronavirus 2019 (COVID-19). Edukatif: Jurnal Ilmu Pendidikan, 2(1), 28-37. https://doi.org/10.31004/edukatif.v2i1.80

Setiawan, R. H., \& Harta, I. (2014). Pengaruh Pendekatan Open-Ended Dan Pendekatan Kontekstual Terhadap Kemampuan Pemecahan Masalah Dan Sikap Siswa Terhadap Matematika. Jurnal Riset Pendidikan Matematika, 1(2), 241. https://doi.org/10.21831/jrpm.v1i2.2679

Shoimin, A. (2014). 68 Model Pembelajaran Inovatif dalam Kurikulum 2013. ArRuzz Media.

Sutiawan, I. (2017). Penggunaan Pembelajaran Creative Problem Solving (Cps) Dalam Upaya Meningkatkan Kemampuan Pemecahan Masalah Matematis Dan Self Efficacy Siswa Smp. Tesis Universitas Pasundan.

How to cite : Naila, N. F., Lukman, E. H., \& Vera, M. S., 2020. Pengaruh Model Pembelajaran Creative Problem Solving dalam Pembelajaran Jarak Jauh terhadap Kemampuan Pemecahan Masalah Matematis Siswa SMP Negeri 3 Jakarta. Jurnal Riset Pendidikan Matematika Jakarta. 2(1). 14-24. https://doi.org/10.21009/irpmi.v2i1.12123

To link to this article: $\underline{\text { https://doi.org/10.21009/jrpmj.v2i1.12123 }}$ 